University of Michigan Law School

University of Michigan Law School Scholarship Repository

1911

\title{
Power of Governor-General to Expel Resident Aliens from Insular Territory of the United States
}

Horace LaFayette Wilgus

University of Michigan Law School

Available at: https://repository.law.umich.edu/articles/1118

Follow this and additional works at: https://repository.law.umich.edu/articles

Part of the Immigration Law Commons, Legal History Commons, and the Legislation Commons

\section{Recommended Citation}

Wilgus, Horace LaFayette. "Power of Governor-General to Expel Resident Aliens from Insular Territory of the United States." Mich. L. Rev. 9 (1911): 412-22.

This Response or Comment is brought to you for free and open access by the Faculty Scholarship at University of Michigan Law School Scholarship Repository. It has been accepted for inclusion in Articles by an authorized administrator of University of Michigan Law School Scholarship Repository. For more information, please contact mlaw.repository@umich.edu. 


\section{Michigan Law Review}

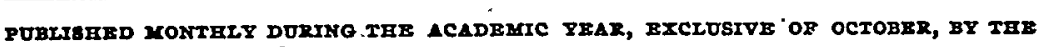
UN FACULT OF THE UKIERSTT OF AICHICAN

suescription Pntce 2.60 pEn YeAh.

36 cENTs PER NUMBER

JAMIPS H. BRIWSTRR, Editor

Evans Hol,BroOK, Acting Fditor

ADVISORY BOARD:

HANRY M. BATES

VICTOR H. LANE

HORACE L. WILGUS

Edstorlal Asfistants, appointed by the Faculty from the Class of 1911: $\triangle$ ARTEOR J. $\triangle$ BBOTI, of Michigan. HOWARD I. BARXDUII, of Ohio.

ALIEN MCK. BOND, of Kentucky. H. STANLEY MCCALL, Of OhIO. I,EON F. MINER, of Michigan.

Howard F. CAMPBELL, of Micbigan. WM. W. MONTGOxrRY, of Washington. Charles I. Cunninegam, of Pennsyltania. JoHN C. MURraY, of California. VICTOR H. NYSEWANDER, of Mrichigan. BEX G. DEWrY, of Ohio. EprowD C. Drckinsor, of Indiana. JOHN S. PRESCOTT, of Michigan. MCKEE RoBISON, of Michigan. FRED J. SIATER, of New York. CUARENCE E. FiDRIDGE, of Michigan. BORTON A. TYLER, of Illinois. JOSEPE F. GOLDSBEXRY, of Ohlo. FXeD S. ZICK, of Tllinols.

\section{NOTE AND COMMENT.}

Power of The Governor GeNeral, to Expei Resident AliENS From the INSULAR TERRTTORY OF THE UNITED STATES.-In the case of Forbes et al. v. Chuoco Tiaco, decided by the Supreme Court of the Philippine Islands July 30, 1910, 8 Off. Gaz., p. 1778, some of the most interesting, important, and fundamental questions were presented and determined for the time being, but not settled, it is reasonably safe to say until passed upon by the Supreme Court of the United States. The questions involved were whether the Governor General of the Philippine Islands has the power to expel resident Chinese aliens without a hearing or an opportunity to be heard, and whether the Governor, if he exceeded his authority, and those who carried out his orders, 'were civilly liable to the persons deported.

The facts were: August I9, I909, the Chiefs- of Police and Secret Service of the City of Manila, acting under the orders of Governor-General Forbes, between 8 and 9 o'clock in the evening, withoutca warrant, seized Chroco Tiaco, and eleven other persons of Chinese race, six of whom including Tiaco, were merchants and property owners in the Philippines where they had resided from 16 to 35 years, and had wives and children, one having 
been president of the Chinese Chamber of Commerce in Manila. They were taken to the police station, deprived of their certificates of registration and other documents required of Chinese persons, showing lawful residence under the laws, hauled to the water front in a patrol wagon, placed in a launch, and put on board a steamship and, under cover of darkness, after the courts were closed, were shipped to China, without opportunity to say farewell to their families, arrange their business, and without notice that any charge of any kind had been made against them.

On March 29, 1910, these six returned to Manila, and brought habeas corpus proceedings in the Court of First Instance to secure their liberty; the court took them into custody and held them until the immigration authorities passed upon their right to land; three were permitted to land as -members of the exempt class by the immigration authorities, and three were not; pending these proceedings the Governor ordered them all to be sent away again, whereupon action was brought in the Court of First Instance by the three allowed to land against the Governor, Chief of Police, and Chief of the Secret Service, praying for damages and an injunction against redeportation. A temporary injunction was issued; the defendants demurred on the ground that the court had no jurisdiction; the demurrer was overruled, and instead of answering, the defendants applied to the Supreme Court for a writ of prohibition, which was issued; the Court of First Instance issued the writ of habeas corpus in favor of the other three excluded by the immigration authorities.

While the cases were pending on demurrer the Governor sent a message to the Philippine Legislature saying, "In the exercise of the power vested in me by Congress, as Chief Executive of the Philippine Islands," he caused "the deportation of certain Chinamen whose antecedents, character and conduct were such that said Chinamen were recognized as being undesirable troublesome, and dangerous even by the Chinese Chamber of Commerce, to such an extreme that the deportation of the aforesaid Chinamen was then urgently requested by the representative of His Imperial Shinese Majesty, the Emperor of China, the Consul-General resident in Manila. After careful investigation $I$ found that the allegations were reasonable and that the presence of the said persons of Chinese nationality in the Philippines was not only liable to result in serious harm to the Chinese colony, but that it might and as the investigation showed, did constitute a serious menace to public order and to the well-being of the whole community," and designated this deportation as one of the subjects to be considered by them.

The Iegislature thereupon, reciting the statements of the Governor's message, passed an act, to the effect that "The action of the Governor-General is hereby approved, and ratified and confirmed and in all respects de- clared legal and not subject to question or review."

At the outset a question was raised whether the suit by the Chinamen was against the defendants in their official, or in their personal, capacity. The Court of First Instance held the latter. Three of the judges of the Supreme Court held the suit was against the defendants in their official capacity and two of them held it was only against them in their personal capacity, 
but all agreed in making the writ of prohibition permanent, and ordering the -suit of the Chinamen dismissed.

Judge Johnson with whom AreLt,ANO, C.J., and TorrFs, J., concurred, held: (I) That the Government of the United States in the Philippine Islands is a government possessed with "all the military, civil, and judicial powers necessary to govern the Philippine Islands," and as such has the power and duty, through its political department, to deport aliens whose presence in the territory is found to be injurious to the public good and domestic tranquility of the people.

(2) That the Governor-General, acting in his political and executive capacity is invested with plenary power to deport aliens whose continued presence in the territory is found by him to be injurious to the public interest, and in the absence of express and prescribed rules as to the method of deporting or expelling them he may use such methods as his official judgment and good conscience may dictate.

(3) That this power to deport or expel obnoxious aliens being invested in the political department of the Government, the judicial department will not, in the absence of express legislation, intervene for the purpose of controlling such power, nor for the purpose of inquiring whether or not he is liable in damages for the exercise thereof.

The opinion of MoRELAND, J., concurred in by TRENT, J., contains an elaborate discussion of the personal liability of the Governor-General for acts in excess of, or without, jurisdiction in the matter, and concludes that the same considerations of public policy which exempt judges of the courts of superior jurisdiction from civil suits for damages for official acts should apply to the Governor-General; that the test of judicial immunity is not jurisdiction, but the exercise of judicial functions; that there is immunity, if the judge is at the time exercising judicial functions, whether within, in excess of, or entirely without, his jurisdiction, and whether he acts maliciously or corruptly or not; that whether a judge has jurisdiction is a question of law, and in determining this question, the judge necessarily exercises judicial functions,- or in other words has jurisdiction to determine what his judisdiction is; that the test of what is a judicial question is whether a qualified judge can regard it as having two sides, or whether there is a real question of law involved; and the test of judicial functions is whether twomen properly qualifed, might really reach different results; but if the matter is so clear that there is or can be no real question, or difference in conclu,sions, it is not a judicial question or function; that whether the GovernorGeneral has authority to expel aliens is a question of law, upon which two qualified persons might easily differ; that he is obliged to determine the question; in doing so he acts judicially, and should be protected.from civil suit for damages; but the courts have authority to review his conclusions and hold them illegal and void, and place as nearly as possible in 'status quo one who has been deprived of his liberty or property by such act.

It will be noted that the majority opinion is based on these propositions: (I) Every independent government has a right to expel aliens; (2) the Philippine government is such; (3) the power is a political one; (4) it re- 
sides in the executive department, that is, the Governor-General; (5) if not, his acts can be ratified by the Legislature. We believe that (2), (4) and (5) are thore than doubtful.

In considering these opinions it is desirable to recall the principal facts relating to the establishment of government of the United States in the Phllyppines. April 19, I 88 , the United States Congress resolved, "That the people of the island of Cuba are and of right ought to be, free and independent," demanded that Spain relinquish its authority over the island, and authorized the President to use the military and naval forces of the United States to carry this resolution into effect. Spain elected to go to war, and Congress declared war, April 25, and directed the President as Commanderin-Chief to carry it on. (30 U. S. St. 364, 738); May 1, Admiral Dewey destroyed the Spanish fleet in Manifa Bay, and the City of Manila was captured August 13, by the naval forces of Dewey and the land forces under General Merritt; by order of the President, May I9, General Merritt was to be military governor with powers "absolute and supreme," but the municipal laws were to remain in force and be administered by the same tribunals so far as possible, as before occupation, but by officials appointed by the government of occupation. December Io, the treaty of Paris was signed by Spain and. the United States, by which Spain ceded the Philippine Islands to the United States, "the civil rights and political status of the native inhabitants" to be determined by the United States Congress, and the Serrate resolved that it was not intended "permanently to annex said islands as an integral part of the territory of the United States."

The Filipinos continued hostile, and military rule, exercising legislative, executive, and judicial functions, continued until September I, I900, when by order of the President April 7, 1900, a Philippine Commission-was created; the Military Governor was to continue to exercise "the executive authority now possessed ijy him not expressly assigned to the Commission," subject however to the order enacted by the Commission in the exercise of the legislative powers conferred upon them; these included various enumerated things and "all other matters of a civil nature for which the Military Governor is now competent to provide by rules or orders of a legislative character," but upon "every branch of the government must be imposed these inviolable rules: that no person shall be deprived of life, liberty or property without due process of law.

March 2, I90I, Congress enacted that "All military, civil and judicial powers necessary to govern the Philippine Islands shall $* * *$ be vested in such person or persons and shall be exercised in such manner, as the President shall direct for the establishment of civil government and for maintaining and protecting the inhabitants in the free enjoyment of their liberty, property, and religion." On June 2I, -I9OI, the President appointed W. H. Taft, Civil Governor, after July 4, I9OI, to exercise "the executive authority in civil affairs," under and in conformity to the instructions $* * *$ dated April 7, I900." July I, 1902, Congress enacted the Philippine Bill, approving the creation of the Philippine Commission by the President, and authorizing it ato exercise "the powers of government to the extent and in the manner 
and form and stubject to the regulation and control. set forth in the instructions" of April 7, 1900, and the creation of the office of Governor-General "to exercise the powers to the extent and in the form set forth in the executive order dated June 2I, IgOI." This bill also defines Philippine citizenship; contains a bill or rights, including the provision that "No law shall be enacted in said Islands which shall deprive any person of life, liberty or property without due process of law, or deny to any person therein the equal protection of the laws;" provides for the organization of a Philippine legislature, and a judiciary, with appellate jurisdiction from the Supreme Court to the United States Supreme Court; also confers authority on the government to do certain things, but all laws passed shall be reported to Congress, which reserves the power to annul the same.

Prior to the conquest and occupation, the Spanish Lraw of Foreigners of 1870 provided "The foreigners who reside in the Spanish provinces shall have the right of security of their persons" as established for Spaniards, which by the Constitutions of 1869 and 1876 , (not extended to the Philippines) required a judgment of a competent court to deport anyone. By royal order of the King of Spain, August 2, 1888, the Governors-General "have authority to determine the legal convenience of deportation which they consider neeessary for the preservation of public order," to be exercised only by the Governor-General himself (and not his subordinates) and subject to revocation by the Supreme Government. In Cuba where this constitutional provision was in effect, it had been held that such provision abrogated any special power of the Governor to deport, and authorized the return of such as had been deported. It was argued that the "due process" clause of the President's order of April 7, 1900, was equivalent to the promulgation of the Spanish constitutional provision. This view seems reasonable.

By Act of Congress of April 29, 1902, the Chinese exclusion acts of the United States were made applicable to the island territory, and required every "Chinese laborer other than a citizen, rightfully in, and entitled to remain in any of the insular territory of the United States". to obtain within a year "a certificate of residence in the insular territory wherein he resides, which certificate shall entitle him to reside therein," and authorized the Philippine Commission to make the rules necessary to enforce these provisions in those islands.

- By the Immigration Act of February 20, 1907, alien idiots, insane, paupers, diseased, criminals, etc., were excluded from the United States, including the Philippines, witl power in the Secretary of Commerce and Labor, when he "shall be satisfied that an alien has been found in the United States. in violation of this Act, or that an alien is subject to deportation under the provisions of this Act or of any law of the United States, to cause such alien within the period of three years after landing or entry therein to be taken into custody and returned to the country whence he came."

By the Constitution of the United States, all legislative power is vested in Congress,-to establish an uniform rule of naturalization; declare war; make all laws necessary and proper to carry into execution the powers vested .in the government or in any department or officer thereof; make all need- 
ful rules and regulations respecting the territory belonging to the United States; but the right of the people to be secure in their persons against unreasonable seizures shall not be violated, and no person shall be deprived of life, liberty, or property without due process of law.

The executive power is vested in the President, who is to swear to faithfully execute the office and preserve, protect, and defend the Constitution; act as commander of the forces when in actual service; make treaties with the advice and consent of the Senate, and take care that the Laws be faithfully executed. The judicial power shall extend to all cases in law and equity atising under this Constitution, and the laws and treaties made thereunder, and which are to be the supreme law of the land.

By the Insular Cases, the Supreme Court of the United States ruled that the territory of the United States included: (1) States; (2) territory incorporated into the Union by declaration of Congress; and (3) territory appurtenant or annexed to the Union by conquest or treaty, but not incorporated into the Union. All of the judges held that all the limitations of the powers of Congress and the guaranties of the Constitution, extended over the States; four of the judges held the same as to all the territory, whether incorporated or appurtenant only; four others held that all the limitations and guaranties included the States and incorporated territory only, but there are certain "limitations of so fundamental character," as to restrain Congress in whatever capacity, or over whatsoever territory, it may be acting; the other judge held that the constitutional limitations and guaranties extended in their full vigor only over the states, but admits that there are some "prohibitions that go to the very root of the power of Congress to act at all," and suggests that: the right to personal liberty, due process of law, equal protection of the laws, immunity from unreasonable seizures, are probably of this class. (Downes v. Bidzell, 182 U. S. 24I, 2I S. C. Rep. 770). In Hazraii v. Mankichi, 190 U. S. 197, 23 S. C. 787 , it was held the provisions of the 5 th and 6 th Amendments as to indictment by grand jury, and trial by petit jury, did not apply to Hawaii, which had been annexed to the United States; and in Dorr v. U. S., 195 U. S. 138,24 S. C. Rep. 808 , it was held that trial by jury was not a necessary incident to due process of law in the Philippines.

From the foregoing it is reasonable to say that the "due process of law" provisions, by the direction of the President, by authority of Congress, and cx proprio rigore, extend over the territory and inhabitants of the Philippine Islands. and have the same effect as in the United States. Weems v. U.S., 217 U. S. 349.

While "due process of law" does not require judicial trial, and the decision of an administrative officer duly authorized by Congress to pass on the matter, no abuse of authority being shown, may be final as to the status of a particular individual, if depending on facts only, it will not be so if depending on matter of law, and the courts will then review administrative acts. Dazies v. Manolis, 179 Fed. 818; U. S. v. Ju Toy, 198 U. S. 253, 25 S. C. Rep. $6.14 ;$ U. S. v. IVilliams, 194 U. S. 279; Gonsales v. Williams, 192 U. S. I, 24 S. C. Rep. 17I; Japanese Immigration Case, I89 U. S. 86 . But "due process of law" whether in court or before an administrative officer re- 
quires "notice and an opportunity to be heard," Garfield v. Goldsby, 2 II U. S. 249. ḾCGEHEE, DUE PrOCESS of LAw, pp. 73-84

In Wong Wing v. U. S., 163 U. S. 228, 237, it was said "No limits can be put by the courts upon the power of Congress to protect, by summary methods, the country from the advent of aliens whose race or habits render them. undesirable as citizens, or to expel such if they have already found their way into our land and unlawfully remain therein. But to declare unilawful residence within the country to be an infamous crime, punishable by deprivation of liberty and property, would be to pass out of the sphere of constitutional legislation, unless provision were made that the fact of guilt should first be established by a judicial trial." And as to a Chinaman already lawfully domiciled in the United States, "while he lawfully remains here he is entitled to the benefit of the guaranties of life, liberty, and property, secured to all persons of whatever race, within the jurisdiction of the United States. His personal rights when he is in this country are as fully protected by the supreme law of the land as if he were a native or naturalized citizen of the United States." Lem Moon Sing v. U. S., I58 U. S. 538, on 547.

Again by the Immigration Treaties of 1880 , and 1894 , Chinese then permanently residing in the United States, or lawfully there were to be protected as the subjects of the most favored nations. By the Io-year exclusion act of I882, Chinese laborers who were here prior to 1880 , were considered to be lawfully here, as were domiciled Chinese merchants and those not laborers, Lau Oze Bew v. U. S., I44 U. S. 47; one brought before a United States Court or Commissioner and found unlawfully in the United States could be deported, but if tried by a Commissioner, he had a right of appeal to the District Court. By Act of 1892 , the exclusion was to continue for Io years more, the former laws were to continue in force, and any Chinese person arrested under any of these laws was to be deemed unlawfully in the United States unless he could affirmatively prove otherwise, Le Sirng v. U. S., 180 U. S. 486 , 2I S. C. Rep. 449 , but those lawfully in the United States at the time were given six months to get certificates of that fact from the internal revenue collectors, and any Chinaman found to be unlawfully in the United States was to be imprisoned at hard labor for a year, and then deported. In Ig02, these laws were continued in force and made applicable to the Philippines.

If this review is correct, then Congress has legislated on the subject of exclusion of aliens, including Chinese, throughout the territory of the United States, and no power is conferred upon the President or any officer anywhere, to deport a resident alien not unlawfully,-i.e., in violation of some of the exclusion acts,-in the United States; there is no power conferred by Congress upon anyone to deport any such, except that, under the Alien Enemy Act of 1798 , in time of war, and in case of actual or threatened invasion, the President by proclamation is authorized to direct the conduct to be observed toward alien enemies, the restraint to be put upon them, and to provide for the removal of such as are directed, but refuse, to depart.

Whether Congress itself has the power to direct alien friends, domiciled and resident within the United States, coming under the comity of friendship 
and good will, pursuing the peaceful pursuits of lawful business, to be seized and deported without charge of violation of law, without notice, and without opportunity to be heard, is more than doubtful. The only time when such attempt has been made in our history was under the Alien Friends Law of 1798 , which witl the sedition act of the same year, as Von Holst says, "Sealed the fate of the Federal party and gave rise to the doctrine of nullification." Even Hamilton said they "appear to me highly exceptionable $* * *$ Let us not establish a tyranny"; and they called forth the famous Kentucky and Virginia Resolutions of 1798 , the first framed by JEFFERSON, and the latter by MADison.

This law conferred upon the President "power to send away all such aliens as he judged dangerous to the peace and safety of the United States, or had reason to think were hatching treason or laying plots against the government. Should any one so ordered to depart be found at large, without license to remain, he might be imprioned for three years and could never become a citizen. Aliens imprisoned in pursuance of the act were subject to removal from the country on the order of the President, and on voluntarily returning, to reimprisonment for such time as the President might think the public good required." Aliens sent away were to be allowed to carry their goods and chattels or dispose of them as they pleased. The law was to last only two years. (McMaster, Hist. of People of U. S., Vol. I., p. 395.) It was never enforced.

Objections to it were: (I) It subverted the general principles of free government; (2) it was contrary to the letter and spirit of the constitution; (3) no power over alien friends was delegated to Congress, but they were under the protection of the states wherein they dwelt; (4) the migration of persons that the states think fit to admit was not to be prohibited by Congress prior to I808; (5) imprisonment without accusation, hearing, trial by jury, confronting accusers, or attendance of witnesses, for failing to obey the President's order to depart, deprived such persons of their liberty without due process of law.

These were answered by the Federalist Committee of the House of Representatives: (I) The migration provision was to prevent Congress from abolishing the slave trade prior to 1808 , and not to prevent the exclusion of aliens in general; (2) but if not, exclusion of alien immigrants was one thing, but "to send off, after arrival, emigrants who were dangerous to the peace and safety of the country was quite another thing"; such construction would deny the right of Congress of "driving from the soil a band of men who with arms in their hands had come to invade it"; (3) as to jury trials it was said: the Constitution was made for citizens, not aliens; they had no rights under it; they merely lived in the country and enjoyed the benefit of the laws, not as a right, but as a favor, and this could be recalled at will; jury trials apply to crimes, and removing an alien was neither committing nor punishing such. (McMAster, Hist, People of U. S., Vol. I., p. 4 I7 et seq.)

The second reason is similar to Judge JoHrson's in the case under review. He says: "Suppose, for example, that some of the inhabitants of the thickly populated countries situated near the Philippines should suddenly 
decide to enter, and should without warning appear in one of the remote harbors, and at once land for the purpose of stirring up the inhabitants and inciting dissensions against the present Government. And suppose that the Legislature was not in session; could it be denied that the Governor-General, under, his general political powers to protect the very existence of the Gov-' ernment has the power to take such steps as he may deem wise and necessary for the purpose of ridding the country of such obnoxious and dangerous foreigners?"

- Many Federalists believed this Alien Act valid; the Anti-Federalists believed otherwise; St. George Tucker declares it invalid (TUckER's BLAckSTONE, Vol. I., p. 30I) ; Judge STORY and Judge COOLEY are non-comimittal (Cooley's Story's Const. LAw, § I294), but Von Holst says "for a long time, they (the Alien and Sedition laws) have been considered in the United States as unquestionably unconstitutional." (ConsrL. HIST., Vol. I., p. I42). The courts did not pass on them.

The foregoing relates to the power of Congress to confer such power on the President; and if Congress has no such power to confer, much less would it.exist in him or in any offcer, unless it inheres in the nature of his office; but if so, it is also subject to the due process provisions of the Constitution, for no department of our government is above the Constitution.

It is not doubted that by the law of nations every sovereign and independent nation has the inherent and inalienable right to expel alien friends subject only to the constitutional restraints it has placed upon itself, Fong Yue Ting v. U. S., I 49 U. S. 709. This power is vested in the political department of the government, regulated by treaty or Act of Corigress (with us), executed by the executive authority, without interference by the judicial authority except so far as treaty, statute, or constitutional provision requires. Ekiu v. U. S., I42 U. S. 65I; Turner v. Williams, 194 U. S. 279; U. S. v. Ju Toy, I98 U. S. 253; Chin Yow v. U. S., 208 U. S. 8.) WILLOUGHBY, Const. LAw, p. 253. But any arbitrary expulsion may give rise to a diplomatic claim for relief. (Moore, Digest Int. L., § 550.)

In England resident alien friends so long as they behave peaceably, are under the .King's protection "though liable to be sent.home whenever the King sees occasion." (I BL. CoMs., p. 260), but all merchants, by the Great Charter of John (c. 4I) shall have a right to come and stay in England for the exercise of trade, except in time of war? in the Charter of Henry III. (c. 30$)$ the same right was continued, "unless publicly prohibited beforehand," which public prohibition must be made by Parliament according to Lord COKE (2 Inst. c. 30). So too no freeman was to be exiled except by the law of the land; the Crown has not exercised this right of expulsion since 1575. During the French Revolution, in 1793, Parliament passed an Alien Act authorizing the Secretary of State to remove such French refugees. as were suspected of conspiracies against the Government, and during the disturbances of 1848 a similar act was passed authorizing the executive to remove foreigners considered dangerous to the public peace, but the power, in neither case, was exercised. Both acts were to last for one year but the first was renewed from time to time till 1826. (TASWELL-LANGMEAD ENGLISH 
Const. HIST., p. 667 note; LAwS of ENGLANd, Ed. by I,ORd HALSBURY, Vol. I., p. 320, II 705; Musgrove v. Chun Teeong Toy [189I] A. C. 272.) Under the present law of England, the Secretary of State may order an alien out of the country if a court (including a court of summary jurisdiction) certifies he has been convicted of a crime, and recommends expulsion, or if such court, after proceedings taken for the purpose within 12 months after the alien last entered the United Kingdom, certifies that the alien is destitute, vagrant, lives in crowded and unsanitary conditions, or has been elsewhere convicted of crime.

In England, the Crown enjo:s the sole right, in his absolute arscretion, acting upon the advice of his cabinet to make treaties, declare war and peace, unfettered by direct supervision by Parliament or otherwise, - subject in recent years to the convention that foreign relations will conform to the wishes of Parliament. The Laws of England, Vol. 6, Consti. LAw, p. 427.) The President of the United States has no such prerogative, and much less the Governors of the states and rerritories.

In colonies before representative legislatures have been granted the Crown has the prerogative right of establishing laws, but not such as are contrary "to the fundamental principles of the British Constitution, or exempting them from the power of Parliament, and every colony is subject to the paramount authority of the Imperial Parliament." (LAws of ENGLAND, Vol. 6, p. 423). In Canada, (Const. 9I [25]) ; Australia (5I, XIX), and South Af. rica (139) some power is conferred by their constitutions to legislate on naturalization and aliens, but the Naturalization Act of $18 \% 0$ ( 33 \& 34 Vict. c. I4); is controlling in many respects in the colonies. (WooLSEY, CoMparATive Study of South Arricar Consr., Am. J. Int. Law, Jan., Iglo, p. 80.) In the colonies the colonial legislatures have of course such powers 'as the King by his prerogative can exercise, or has authorized, (Attorncy General v. Cain, H. L. App. Cas. 1906, p. 545) or Parliament has bestowed upon them (Hodge v. Reg., 9 App. Cas. II7), neither of which is limited by "due process of law" provisions of the Federal constitution.

Prior to the revolution the American Colonies enacted laws regulating the admission of aliens; this power continued in the States under the Confederation; the regulations were so diverse that Madison proposed a uniform rule as early as 1782 . It was natural, therefore, to confer such power on Congress under the Constitution. While it was at first conside $d$ that this power was concurrent with that of the State (Collet v. C Let, 2 Dallas 294) yet it has long been settled that the power of naturalization is exclusively vested in Congress, (Van Dyne, Naturalization, p. 6), and it would seem also that under the treaty making power vested in the United States, that the States cannot admit or keep, those -whom the Federal Government excludes, although in the absence of exclusion acts of Congress the States may undoubtedly admit whom they please, though probably not expel those whom the Federal Government admits. Wrisougmby, CoNST. LAw, §§ raz-5, 128-I32.)

It would seem from this that Congress has not and probably cannot, nor has ar can the President, confer on the Philippine Legislature or the Gover- 
nor-General, the power to do what the Governor did in the case under review, in the way he did it; that his acts were unauthorized and void; and this for the reason that probably Congress could not lawfully under the Constitution do or cause them to be so done itself; that the Philippine government,-Legislative or Executive, is not an independent and sovereign government in the international sense, in which there inheres any political power of an international or diplomatic kind, to deport aliens, not violating laws, or charged with some offense. Such power is vested exclusively in the Congress of the United States.

If this is so then there is much authority for holding the Governor or his subordinates civilly liable, (Hendricks v. Gonzales, 67 Fed. R. 351 ; Kilbourn v. Thompson, i03 U. S. I68;.U. S. v. Lee, 106 U. S. 196; Head v. Porter, 48 Fed. 481 ; Lorsch v. Kochler, I 44 Ind. 278; Blair v. Struck, - Mon. -, 74 Pac. 69; Bclknap v. Schild, 16I U. S. 18; Little v. Barrcme, 6 U. S. (2 Cr.) 170; Bates v. Clarke, 95 U. S. 204; Mostyzt v. Fabrigas, I Cowp. 150; although probably the decisions in the United States are the other way in a discretionary, or quasi-judicial function of this kind, (Spalding v. Vilas, I6I U. S. 483, Ió S. C. R. 63I; In re Fair, 10n Fed. I49; Marbury v. Madison, I Cranch 137 ; Kendall v. U. S., I2 Pet. 524, 610; Dccatur v. Paulding, 14 Pet. 497; Coolex, ToRTS (Students' Ed.) p. 375, § 207. 